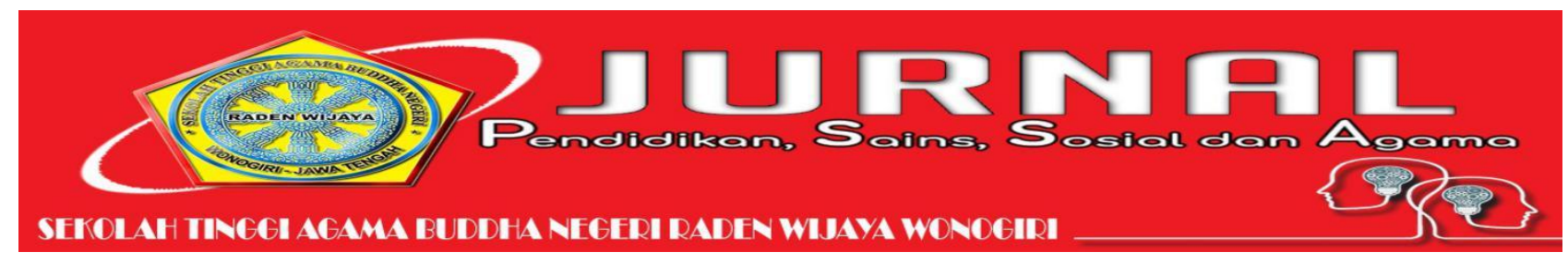

\title{
KEPATUHAN WAJIB PAJAK: INVESTIGASI EMPIRIS PADA INDUSTRI PERHOTELAN
}

\author{
Sulistiyorini $^{1}$, M. Elfan Kaukab ${ }^{2}$, Wiji Yuwono ${ }^{3}$ \\ Universitas Sains Al-Qur'an, Wonosobo, Indonesia \\ sulistiyorini056@gmail.com, elfan@unsiq.ac.id, wiji.yuwono.psc20@mail.umy.ac.id
}

\begin{abstract}
Abstrak
Tujuan untuk membuktikan pengaruh kesadaran wajib pajak, kualitas pelayanan, pemahaman peraturan, kewajiban moral, sanksi pajak, dan sanksi pajak terhadap kepatuhan wajib pajak hotel pada Badan Pendapatan Daerah Kabupaten Banyumas. Jumlah sampel dalam penelitian ini menggunakan rumus Slovin, jumlah sampel berdasarkan perhitungan rumus adalah 36 Wajib Pajak. Teknik sampling menggunakan simple random sampling atau penarikan sampel acak. Model yang digunakan untuk menguji hipotesis dalam penelitian ini menggunakan analisis regresi linier berganda. Hasil penelitian menunjukkan bahwa kesadaran wajib pajak, kualitas pelayanan, kewajiban moral, dan sanksi pajak tidak berpengaruh terhadap kepatuhan wajib pajak. Sedangkan pemahaman peraturan dan aplikasi satria pajakberpengaruh positif terhadap kepatuhan wajib pajak. Keterbatasan dari penelitian ini adalah sampel yang terlalu kecil sehingga disarankan untuk penelitian berikutnya dapat memperluas cakupan responden amatan.
\end{abstract}

Kata Kunci: kesadaran wajib pajak, kualitas pelayanan, pemahaman peraturan, kewajiban moral, sanksi pajak, sanksi pajak, kepatuhan wajib pajak

\begin{abstract}
The aim is to prove the effect of taxpayer awareness, service quality, understanding of regulations, moral obligations, tax sanctions, and tax sanctions on hotel taxpayer compliance at the Banyumas Regency Regional Revenue Agency. The number of samples in this study using the Slovin formula, the number of samples based on the calculation of the formula is 36 taxpayers. The sampling technique uses simple random sampling or random sampling. The model used to test the hypothesis in this study uses multiple linear regression analysis. The results showed that taxpayer awareness, service quality, moral obligation, and tax sanctions had no effect on taxpayer compliance. Meanwhile, understanding the regulations and the application of tax officers has a positive effect on taxpayer compliance. The limitation of this study is that the sample is too small, so it is suggested that future studies can expand the scope of the observed respondents.
\end{abstract}

Key Word: taxpayer awareness, service quality, understanding of regulations, moral obligations, tax sanctions, tax sanctions, taxpayer compliance 


\section{PENDAHULUAN}

Pajak sebagai salah satu penerimaan negara memiliki peran yang sangat besar dan semakin diandalkan dalam kepentingan pembangunan serta pembiayaan pengeluaran pemerintah (Mas dan Ery, 2014 dalam Dewi dan Sukartha, 2015). Pajak daerah dan retribusi daerah merupakan sumber pendapatan daerah yang penting guna membiayai penyelenggaraan pemerintah daerah dan pembangunan daerah untuk mendapatkan otonomi daerah yang nyata, dinamis, serasi, dan bertanggung jawab (Dharma dan Suardana, 2014).

Menurut Undang-Undang No. 22 Tahun 2016 tentang Peraturan Daerah Kabupaten Banyumas menetapkan jenis pajak daerah terdiri atas pajak hotel, pajak restoran, pajak hiburan, pajak reklame, pajak penerangan jalan, pajak mineral bukan logam dan batuan, pajak parkir, pajak sarang burung walet, pajak air tanah, pajak bumi dan bangunan perdesaan dan perkotaan.

Penelitian ini berfokus pada salah satu jenis pajak daerah yang mempengaruhi pendapatan asli daerah yaitu pajak hotel. Berdasarkan Undang-Undang No. 22 Tahun 2016 tentang Peraturan Daerah Kabupaten Banyumas, pengertian pajak hotel adalah pajak atas pelayanan yang disediakan oleh hotel. Hotel adalah fasilitas penyedia jasa penginapan/peristirahatan termasuk jasa terkait lainnya dengan dipungut bayaran, yang mencakup juga motel, losmen, gubug pariwisata, wisma pariwisata, pesanggrahan, rumah penginapan dan sejenisnya, serta rumah kos dengan jumlah kamar lebih dari 10 (sepuluh). Pajak hotel adalah pajak yang secara tidak langsung dibayarkan oleh masyarakat yang menikmati pelayanan di hotel kepada pemerintah melalui hotel yang bersangkutan. Namun tidak semua Wajib Pajak hotel akan melaksanakan kewajibannya, sehingga dapat menjadikan kendala dalam pengumpulan pajak. Salah satu kendala yang dapat menghambat keefektifan pengumpulan pajak adalah kepatuhan wajib pajak (Pratiwi dan Aryani, 2019).

Menurut Green (1991) kepatuhan dapat diartikan sebagai suatu perubahan perilaku dari perilaku yang tidak taat peraturan ke perilaku yang taat peraturan.Wajib Pajak patuh akan kewajibannya karena menganggap kepatuhan terhadap pajak adalah suatu norma (Lederman, 2003). Kepatuhan pajak merupakan masalah klasik yang dihadapi dihampir semua negara yang menganut sistem perpajakan (Hutagaol, 2007).

Tinggi rendahnya kepatuhan wajib pajak dapat dipengaruhi oleh kesadaran wajib pajak. Masyarakat harus sadar akan keberadaannya sebagai warga negara yang senantiasa selalu menjunjung tinggi Undang-Undang Dasar 1945 sebagai dasar hukum penyelenggaraan negara (Suardikha, 2009). Kesadaran wajib pajak merupakan suatu keadaan disaat Wajib Pajak mengetahui, memahami, dan melaksanakan ketentuan perpajakan secara benar dan sukarela (Asri, 2009). Hasil penelitian yang dilakukan oleh Nirajenani dan Aryani (2018) membuktikan bahwa kesadaran wajib pajak berpengaruh positif pada kepatuhan wajib pajak.

Gap theory yang diusulkan oleh Parasuraman, dkk (1985) menyatakan bahwa kualitas pelayanan merupakan perbandingan antara harapan yang diinginkan oleh pelanggan dengan penilaian mereka terhadap kinerja aktual dari suatu penyediaan layanan.Kualitas pelayanan tidak hanya dianggap penting oleh perusahaan komersial saja tetapi saat ini instansi pajak juga telah merasakan betapa pentingnya kualitas pelayanan karena instansi pajak juga memiliki pelanggan yakni Wajib Pajak (Alabede et al, 2011). Hasil penelitian yang dilakukan oleh Layata dan Setiawan (2014) membuktikan bahwa kualitas pelayanan berpengaruh positif pada kepatuhan wajib pajak.

Pemahaman akan peraturan perpajakan akan meningkatkan kepatuhan seseorang dalam memenuhi kewajiban perpajakannya (Haryanti dan Kaukab, 2019). Masalah tingkat pemahaman akan peraturan perpajakan dari wajib pajak dirasa perlu untuk dibahas karena pengetahuan perpajakan adalah salah satu faktor potensial bagi pemerintah untuk meningkatkan kepatuhan wajib pajak dalam memenuhi kewajiban perpajakannya. Apabila wajib pajak memahami peraturan perpajakan yang dimiliki maka akan mempengaruhi patuh tidaknya wajib pajak itu sendiri dalam melaksanakan kewajiban perpajakannya (Nirajenani dan Aryani, 2018). 
Kewajiban moral adalah moral yang berasal dari masing-masing individu yang kemungkinan orang lain tidak memilikinya (Ajsen, 2002). Menurut Wenzel (2005) moral wajib pajak, etika dan norma sosialnya sangat berpengaruh terhadap perilaku dari Wajib Pajak. Pernyataan tersebut didukung dengan hasil penelitian Layata dan Setiawan (2014) membuktikan bahwa kewajiban moral berpengaruh positif pada kepatuhan wajib pajak.

Sanksi perpajakan dapat dikenakan agar memberikan efek jera bagi wajib pajak yang kurang taat terhadap kewajibannya sebagai seorang Wajib Pajak (Ngakil dan Kaukab, 2020). Sanksi yang dikenakan dalam jumlah yang tinggi akan mendorong Wajib Pajak untuk lebih patuh (Wahyu, 2008). Penelitian yang dilakukan oleh Jaya dan Jati (2016) membuktikan bahwa sanksi perpajakan berpengaruh positif pada kepatuhan wajib pajak.

Aplikasi satria pajak merupakan sistem pembayaran pajak daerah secara online pada
Badan Pendapatan Daerah Kabupaten Banyumas. Aplikasi satria pajak melayani pajak hotel, pajak restoran, pajak hiburan, pajak reklame, pajak penerangan jalan, pajak mineral bukan logam dan batuan, pajak parkir, pajak air tanah.Aplikasi satria pajak diciptakan agar wajib pajak dapat lebih mudah, aman, praktis, dan sesuai dengan ketentuan dalam membayar pajaknya. Menurut Pak Toro kepala sub bidang penagihan Badan Pendapatan Daerah Kabupaten Banyumas aplikasi satria pajak merupakan sistem pembayaran pajak daerah secara online yang sangat berpengaruh terhadap tingkat kepatuhan wajib pajak hotel di Kabupaten Banyumas.

Pajak hotel menjadi salah satu pendapatan daerah yang terus digenjot untuk dimaksimalkan. Namun di tahun 2019 pajak hotel yang ditarget Rp 11,5 miliar, realisasinya baru Rp 10 miliar. Hal ini dapat dilihat dari jumlah target dan realisasi yang disajikan pada Tabel 1 berikut:

Tabel 1 Target dan Realisasi Penerimaan Pajak Hotel pada BAPENDA Kabupaten Banyumas Tahun 2015 Sampai 2019

\begin{tabular}{|c|c|c|c|c|}
\hline \multirow{2}{*}{ Tahun } & \multirow{2}{*}{ Target (RP) } & \multicolumn{2}{|c|}{ Realisasi } & \multirow{2}{*}{$\begin{array}{c}\text { Pertumbuhan } \\
(\%)\end{array}$} \\
\hline & & $\mathrm{Rp}$ & $(\%)$ & \\
\hline 2015 & $5,500.000 .000$ & 6.025 .201 .413 & 110 & - \\
\hline 2016 & 6.500 .000 .000 & 6.864.568.010 & 106 & 13,93 \\
\hline 2017 & 7.400 .000 .000 & 7.708.131.245 & 104 & 12,29 \\
\hline 2018 & 10.000 .000 .000 & 10.387.206.836 & 104 & 34,76 \\
\hline $2019 *$ & 11.500 .000 .000 & 10.494 .017 .326 & 91,25 & 1,03 \\
\hline \multicolumn{3}{|c|}{ Rata-rata } & 103,05 & 12,40 \\
\hline
\end{tabular}

Sumber: BAPENDA Kabupaten Banyumas, 2020.

persentase pada tahun-tahun sebelumya. Selain

Berdasarkan Tabel 1 realisasi pajak lebih rendah dari yang ditargetkan dan hanya memiliki persentase $91,25 \%$ lebih rendah dari itu pertumbuhannya juga sangat kecil yaitu $1,03 \%$, yang dapat menunjukan masih kurangnya tingkat kepatuhan wajib pajak.

Tabel 2 Piutang Pajak Hotel Di Badan Pendapatan Daerah Kabupaten Banyumas Tahun 2015 Sampai 2019

\begin{tabular}{cccc}
\hline Tahun & $\begin{array}{c}\text { Jumlah piutang } \\
\text { awal }\end{array}$ & $\begin{array}{c}\text { Jumlah realisasi } \\
\text { piutang }\end{array}$ & Jumlah piutang \\
\hline 2015 & 26.825 .970 & 16.720 .500 & 10.105 .470 \\
2016 & 10.105 .470 & 1.432 .750 & 8.672 .720 \\
2017 & 8.672 .720 & - & 8.672 .720 \\
2018 & 8.672 .720 & - & 8.672 .720 \\
2019 & 8.672 .720 & - & 8.672 .720 \\
\hline
\end{tabular}

Sumber: BAPENDA Kabupaten Banyumas, 2020. 
Dari Tabel 2 membuktikan bahwa terdapat piutang yang belum ter realisasi sejumlah 8.672.720 dari tahun 2017 sampai 2019. Tabel 2 mengindikasikan bahwa masih terdapat Wajib Pajak hotel yang tidak patuh atau kurang dalam menjalankan kewajiban perpajakannya. Kepatuhan wajib pajak merupakan faktor yang sangat penting bagi peningkatan penerimaan pajak, maka dari itu perlu dikaji secara intensif mengenai faktorfaktor yang mempengaruhi kepatuhan wajib pajak, khusunya dalam membayar pajak hotel (Chau, 2009).

\section{LANDASAN TEORI DAN PENGEMBANGAN HIPOTESIS}

Seorang Wajib Pajak harus dengan sadar memahami, menaati, dan memiliki kesungguhan untuk memenuhi kewajiban ketentuan perpajakan dengan baik dan benar, yang sudah diatur pemerintah dalam perundang-undangan (Dewi dan Sukartha, 2015). Semakin tinggi tingkat kesadaran wajib pajak, maka pemahaman dan pelaksanaan kewajiban perpajakan semakin baik sehingga dapat meningkatkan kepatuhan (Sugi dan Lely, 2017 dalam Nirajenani dan Aryani, 2018 ). Hasil penelitian yang dilakukan oleh Dewi dan Sukartha (2015) menunjukan bahwa kesadaran wajib pajak berpengaruh positif pada kepatuhan wajib pajak.Hasil tersebut sejalan dengan hasil penelitian yang dilakukan oleh Jaya dan Jati (2016) Kesadaran wajib pajak berpengaruh positif pada kepatuhan wajib pajak. Hasil penelitian tersebut juga sejalan dengan penelitian yang dilakukan oleh Nirajenani dan Aryani (2018) kesadaran wajib pajak berpengaruh positif terhadap kepatuhan wajib pajak. Berdasarkan uraian diatas dapat disimpulkan bahwa semakin tinggi kesadaran wajib pajak maka pemahaman dan pelaksanaan kewajiban perpajakan semakin baik sehingga dapat meningkatkan kepatuhan, sehingga dapat disusun hipotesis sebagai berikut:

$H_{1}$ : Kesadaran wajib pajak berpengaruh positif terhadap kepatuhan wajib pajak.

Kualitas pelayanan yang baik merupakan salah satu upaya dalam meningkatkan kepatuhan wajib pajak.Kualitas pelayanan petugas yang baik diharapkan dapat meningkatan kepuasan wajib pajak sehingga meningkatkan kepatuhan dalam memenuhi kewajiban perpajakannya. Pelayanan petugas yang baik akan memberikan kenyamanan bagi Wajib Pajak. Salah satu upaya yang dapat dilakukan guna meningkatkan kualitas pelayanan yaitu dengan menyediakan saranaprasarana maupun sistem informasi terutama dalam pembentukan perilaku petugas yang siap melayani masyarakat selaku Wajib Pajak (Nirajenani dan Aryani, 2018). Hasil penelitian yang dilakukan oleh Layata dan Setiawan (2014) membuktikan bahwa kualitas pelayanan berpengaruh positif pada kepatuhan wajib pajak.Hasil penelitian tersebut sejalan dengan penelitian yang dilakukan oleh Pranata dan Setiawan (2015) bahwa kualitas pelayanan berpengaruh positif pada kepatuhan wajib pajak. Hasil tersebut juga sejalan dengan penelitian yang dilakukan oleh Rahayu (2015) bahwa kualitas pelayanan mempengaruhi kepatuhan wajib pajak. Berdasarkan uraian sebelumnya dapat disimpulkan bahwa kualitas pelayanan petugas yang baik diharapkan dapat meningkatan kepuasan wajib pajak sehingga meningkatkan kepatuhan dalam memenuhi kewajiban perpajakannya, sehingga dapat disusun hipotesis sebagai berikut:

\section{$\mathrm{H}_{2}$ : Kualitas pelayanan berpengaruh positif terhadap kepatuhan wajib pajak.}

Susilawati dan Budiartha (2013), menyatakan bahwa pemahaman mengenai arti dan manfaat pajak dapat meningkatkan kesadaran dari wajib pajak. Faktor pengetahuan khususnya pengetahuan dasar tentang perpajakan penting dalam membantu wajib pajak melaksanakan kewajibannya (Noormala, 2008). Sikap wajib pajak dapat ditingkatkan melalui pengetahuan pajak yang lebih baik dan pada gilirannya akan meningkatkan kepatuhan secara sukarela dan mengurangi kecenderungan untuk menghindari pajak (Eriksen, 1996). Hasil penelitian Nirajenani dan Aryani (2018) membuktikan bahwa pemahaman peraturan berpengaruh positif terhadap kepatuhan wajib pajak.Hasil tersebut sejalan dengan penelitian Pratiwi dan Supadmi (2016) pemahaman peraturan berpengaruh positif terhadap 
kepatuhan wajib pajak. Hasil penelitian sebelumnya yang dilakukan oleh Romandana (2012) dan Nerissa (2014) dalam Pratiwi dan Supadmi (2016) mendapatkan hasil bahwa pemahaman peraturan perpajakan berpengaruh positif pada kepatuhan wajib pajak. Berdasarkan uraian sebelumnya dapat disimpulkan Semakin baik pengetahuan perpajakan wajib pajak, semakin patuh wajib pajak memenuhi kewajibannya sesuai dengan peraturan perpajakan, sehingga dapat disusun hipotesis sebagai berikut:

\section{$\mathrm{H}_{3}$ : Pemahaman peraturan berpengaruh positif terhadap kepatuhan wajib pajak.}

Menurut Ajsen (2002) kewajiban moral adalah moral yang berasal dari masing-masing individu yang kemungkinan orang lain tidak memilikinya. Wanzel (2002) menyimpulkan dalam penelitiannya jika Wajib Pajak memiliki kewajiban moral yang baik maka Wajib Pajak akan cenderung berperilaku jujur dan taat terhadap aturan yang telah diberikan sehingga hal ini berdampak pada kepatuhan wajib pajak dalam pemenuhan pajaknya. Pernyataan tersebut didukung dengan hasil penelitian Layata dan Setiawan (2014) membuktikan bahwa kewajiban moral berpengaruh positif pada kepatuhan wajib pajak.Hasil penelitian yang dilakukan oleh Dewi dan Sukartha (2015) juga membuktikan bahwa kewajiban moral berpengaruh positif pada kepatuhan wajib pajak dalam membayar pajak hotel. Hasil tersebut sejalan dengan penelitian Pranata dan Setiawan (2015) yang membuktikan bahwa kewajiban moral berpengaruh positif pada kepatuhan wajib pajak. Berdasarkan uraian sebelumnya dapat disimpulkan bahwa kewajiban moral yang baik diharapkan dapat meningkatan kepatuhan wajib pajak, sehingga dapat disusun hipotesis sebagai berikut:

\section{$\mathrm{H}_{4}$ : Kewajiban moral berpengaruh positif terhadap kepatuhan wajib pajak.}

Menurut Kantor Pemerintah Akuntan Amerika Serikat (2009) dalam Layata dan Setiawan (2014) sanksi perpajakan dimaksudkan untuk membuat patuh para wajib pajak.Sanksi perpajakan dapat diberikan kepada Wajib Pajak yang terlambat menyelesaikan kewajibannya dan juga kepada Wajib Pajak yang melaporkan pajak terutangnya secara tidak benar sesuai dengan jumlah yang seharusnya. Kedua hal ini sangat merugikan karena dapat mempengaruhi pendapatan negara yang secara jangka panjang dapat menghambat pembangunan yang akan dilaksanakan oleh pemerintah guna meningkatkan kesejahteraan masyarakat. Sanksi yang dikenakan dalam jumlah yang tinggi akan mendorong Wajib Pajak untuk lebih patuh (Wahyu, 2008 dalam Jaya dan Jati, 2016). Hasil penelitian Dewi dan Sukartha (2015) membuktikan bahwa sanksi perpajakan berpengaruh positif pada kepatuhan wajib pajak dalam membayar pajak.Hasil penelitian yang dilakukan oleh Jaya dan Jati (2016) juga membuktikan bahwa sanksi perpajakan berpengaruh positif pada kepatuhan wajib. Hasil tersebut sejalan dengan penelitian Nirajenani dan Aryani (2018) yang membuktikan bahwa sanksi perpajakan berpengaruh positif terhadap kepatuhan wajib pajak. Berdasarkan uraian sebelumnya dapat disimpulkan bahwa sanksi perpajakan yang dikenakan dalam jumlah tinggi dapat mendorong Wajib Pajak untuk lebih patuh, sehingga dapat disusun hipotesis sebagai berikut:

\section{$H_{5}$ : Sanksi pajak berpengaruh positif terhadap kepatuhan wajib pajak.}

Aplikasi satria pajak merupakan sistem pembayaran pajak daerah secara online pada Badan Pendapatan Daerah Kabupaten Banyumas.Aplikasi satria pajak juga merupakan sistem pembayaran pajak daerah secara online yang berfungsi untuk mengoptimalkan potensi penerimaan daerah. Aplikasi satria pajak juga berfungsi untuk memfasilitasi Wajib Pajak untuk membayar kewajibannya tanpa perlu datang ke kantor Badan Pendapatan Daerah. Menurut Pak Toro kepala sub bidang penagihan Badan Pendapatan Daerah Kabupaten Banyumas aplikasi satria pajak merupakan sistem pembayaran pajak daerah secara online yang sangat berpengaruh terhadap tingkat kepatuhan wajib pajak hotel di Kabupaten Banyumas. Berdasarkan uraian sebelumnya dapat 
disimpulkan bahwa aplikasi satria pajak yang dapat mempermudah Wajib Pajak dalam membayar kewajibannya dapat mendorong Wajib Pajak untuk lebih patuh, sehingga dapat disusun hipotesis sebagai berikut:

$H_{6}:$ Aplikasi satria pajak berpengaruh positif terhadap kepatuhan wajib pajak.

\section{METODE}

penelitian yang menggunakan angka dalam penyajian data dan analisis yang menggunakan uji statistik. Populasi dalam penelitian ini adalah Wajib Pajak hotel yang terdaftar di Badan Pendapatan Daerah di Kabupaten Banyumas dari tahun 2016-2020 dengan jumlah 417 Wajib Pajak hotel yang terdiri dari 188 hotel, $170 \mathrm{kos}$, dan 59 wisma \& villa. Dengan asumsi bahwa dalam penelitian ini hanya meneliti tentang perhotelan yang ada di Banyumas, jadi jumlah populasinya ada 188 Wajib Pajak. Untuk menentukan jumlah sampel dalam penelitian ini menggunakan rumus Slovin, jumlah sampel berdasarkan perhitungan rumus adalah 36 Wajib Pajak. Teknik sampling menggunakan simple random sampling atau penarikan sampel acak. Model yang digunakan untuk menguji hipotesis dalam penelitian ini menggunakan analisis regresi linier berganda.

Variabel dependen dalam penelitian ini adalah kepatuhan wajib pajak. Adapun indikator kepatuhan wajib pajak yaitu Wajib Pajak mengisi Surat Pemberitahuan Pajak Daerah (SPTPD) dengan benar, melakukan perhitungan dengan benar, melakukan pelaporan atas penyetoran SPTPD dengan tepat waktu, melakukan pembayaran tepat waktu, tidak pernah menerima surat teguran (Pratiwi dan Aryani, 2019). Variabel

independen dalam penelitian ini yaitu kesadaran wajib pajak dengan indicator hak dan kewajiban, tepat waktu, kesadaran diri sendiri (Munawaroh, 2018). Kualitas pelayanan dengan ndikator bukti fisik/berwujud, keandalan, daya tanggap, jaminan, dan empati (Pratiwi dan Aryani, 2019). Indikator pemahaman peraturan yaitu pajak bentuk partisipasi dalam usaha pembangunan nasional, pengetahuan mengenai fungsi perpajakan, wajib pajak diberi kepercayaan (Munawaroh, 2018). Indikator kewajiban moral yaitu tanggungjawab, perasaan cemas, perasaan bersalah (Pratiwi dan Aryani, 2019). Indikator sanksi pajak yaitu sanksi administrasi, sanksi pidana, pengenaan sanksi yang berat untuk mendidik Wajib Pajak (Pratiwi dan Aryani, 2019). Indikator aplikasi satria pajak yaitu mengetahui aplikasi satria pajak, mengetahui fungsi aplikasi satria pajak, mensukseskan kegiatan monitoring pajak secara online Pratiwi dan Aryani (2019). Semua variabel diukur dengan kuesioner dengan 5 poin skala likert.

\section{HASIL}

\section{Hasil}

Uji F merupakan uji Goodness of Fit yang digunakan untuk mengukur ketepatan fungsi regresi sampel dalam menaksir nilai aktual. Hasil pengujian diperoleh nilai $\mathrm{F}$ hitung $=4,574>$ Ftabel $=2,43$, maka Ho ditolak atau Ha diterima, artinya ada pengaruh secara simultan antara kesadaran wajib pajak, kualitas pelayanan, pemahaman peraturan, kewajiban moral, sanksi pajak, dan aplikasi satria pajak terhadap kepatuhan wajib pajak. Sehingga dapat dikatakan bahwa model penelitian sudah baik dan memenuhi kriteria Good of fit.

Tabel 3 Pengujian Good Of fit Model (Uji F)

\begin{tabular}{lrrrrr}
\hline \multicolumn{1}{r}{ Model } & Sum of Squares & df & Mean Square & F & Sig. \\
\hline Regression & 126,788 & 6 & 21,131 & 4,574 &, 002 \\
Residual & 133,962 & 29 & 4,619 & & \\
Total & 260,750 & 35 & & & \\
\hline
\end{tabular}

Sebelum dilakukan pengolahan data, data yang diperoleh melalui kuesioner perlu untuk diuji kebenaran dan kehandalanya. Pengujian dilakukan dengan pengujian validitas dan reliabilitas. Hasil uji validitas menunjukan bahwa variabel kesadaran wajib pajak memiliki kisaran korelasi 0,684** sampai $0,811^{* *}$ dengan tingkat signifikasi 0,000. Hal ini menunjukkan bahwa pertanyaan-pertanyaan tentang kesadaran wajib pajak dapat dinyatakan valid.Variabel kualitas pelayanan memiliki kisaran korelasi 
$0,482 * *$ sampai $0,788^{* *}$ dengan tingkat signifikasi 0,000.Hal ini menunjukkan bahwa pertanyaan-pertanyaan tentang kualitas pelayanan dapat dinyatakan valid.Variabel pemahaman peraturan memiliki kisaran korelasi $0,747 * *$ sampai $0,770 * *$ dengan tingkat signifikasi 0,000 . Hal ini menunjukkan bahwa pertanyaan-pertanyaan tentang pemahaman peraturan dapat dinyatakan valid.Variabel kewajiban moral memiliki kisaran korelasi $0,741 * *$ sampai $0,842 * *$ dengan tingkat signifikasi 0,000 . Hal ini menunjukkan bahwa pertanyaan-pertanyaan tentang kewajiban moral dapat dinyatakan valid.Variabel sanksi pajak memiliki kisaran korelasi $0,828 * *$ sampai $0,955^{* *}$ dengan tingkat signifikasi 0,000 . Hal ini menunjukkan bahwa pertanyaan-pertanyaan tentang sanksi pajak dapat dinyatakan valid.Variabel aplikasi satria pajak memiliki kisaran korelasi $0,636^{* *}$ sampai $0,935^{* *}$ dengan tingkat signifikasi 0,000. Hal ini menunjukkan bahwa pertanyaan-pertanyaan tentang aplikasi satria pajak dapat dinyatakan valid. Variabel kepatuhan wajib pajak memiliki kisaran korelasi $0,706 * *$ sampai $0,929 * *$ dengan tingkat signifikasi 0,000 . Hal ini menunjukkan bahwa pertanyaan-pertanyaan tentang kepatuhan wajib pajak dapat dinyatakan valid. Hasil uji reliabilitas menggunakan Cronbach Alpha dengan hasil semua variabel dalam penelitian memiliki alpha lebih besar dari 0,6 maka hasil penelitian ini menunjukkan bahwa alat pengukuran dalam penelitian ini telah memenuhi syarat uji reabilitas karena reliabel dan dapat digunakan sebagai alat ukur.
Uji asumsi klasik dilakukan sebelum menguji hipotesis. Hasil perhitungan normalitas dengan menggunakan uji One Sample Kolmogorov-smirnov Test memiliki probabilitas tingkat signifikan diatas tingkat $\alpha$ $=0,05$ yaitu 0,170 . Hal ini berarti dalam model regresi terdapat variabel residual yang terdistribusi secara normal. Hasil uji multikolonieritas menunjukkan semua nilai tolerance yakni pada variabel kesadaran wajib pajak, kualitas pelayanan, pemahaman peraturan, kewajiban moral, sanksi pajak, dan aplikasi satria pajak diatas nilai 0,1 . Selain itu pada VIF pada semua variabel yakni kesadaran wajib pajak, kualitas pelayanan, pemahaman peraturan, kewajiban moral, sanksi pajak, dan aplikasi satria pajak menunjukkan nilai kurang dari 10. Sehingga dapat disimpulkan bahwa dalam model regresi ini tidak terjadi gejala multikolonieritas. Hasil uji heterokedastisitas menunjukkan bahwa nilai signifikansi variabel kesadaran wajib pajak, kualitas pelayanan, pemahaman peraturan, kewajiban moral, sanksi pajak, dan aplikasi satria pajak berada diatas 0,05 . Jadi dapat dikatakan bahwa model regresi tidak mengandung adanya heterokedastisitas.

Pengujian hipotesis pada penelitian ini menggunakan regresi linier berganda untuk menguji apakah kesadaran wajib pajak, kualitas pelayanan, pemahaman peraturan, kewajiban moral, sanksi pajak, dan aplikasi satria pajak berpengaruh terhadap kepatuhan wajib

pajak.

Tabel 4 Hasil Uji Analisis Regresi Linier Berganda

\begin{tabular}{lrrrrrr}
\hline \multirow{2}{*}{ Model } & \multicolumn{2}{c}{ Unstandardized } & \multicolumn{2}{c}{ Standardized } & \\
& \multicolumn{2}{c}{ Coefficients } & \multicolumn{2}{c}{ Coefficients } & T & \multirow{2}{*}{ Sig. } \\
\cline { 2 - 4 } & \multicolumn{1}{c}{ B } & Std. Error & Beta & & \\
\hline 1 (Constant) & 4,713 & 4,879 & &, 966 &, 342 \\
Kesadaran WP &, 320 &, 366 &, 141 &, 876 &, 388 \\
Kualitas Pelayanan &,- 076 &, 068 &,- 201 & $-1,121$ &, 271 \\
Pemahaman Peraturan &, 431 &, 210 &, 282 & 2,055 &, 049 \\
Kewajiban Moral &, 485 &, 296 &, 273 & 1,636 &, 113 \\
Sanksi Pajak &,- 077 &, 243 &,- 058 &,- 318 &, 752 \\
Aplikasi Satria Pajak &, 565 &, 171 &, 471 & 3,307 &, 003 \\
\hline
\end{tabular}


Tabel 4 menunjukkan hasil pengujian regresi linier berganda secara serentak terhadap seluruh vaiabel independen dalam penelitian ini. Berdasarkan tabel tersebut dapat diperoleh persamaan regresi linier berganda sebagai beikut:

$\mathrm{Y}=4,713+0,320 \mathrm{X} 1-0,076 \mathrm{X} 2+0,431 \mathrm{X} 3$ $+0,485 \mathrm{X} 4-0,077 \mathrm{X} 5+0,565 \mathrm{X} 6+2,14927$

1. Nilai konstanta $(\alpha)$ sebesar 4,713, menunjukkan bahwa ketika variabel independen (kesadaran wajib pajak, kualitas pelayanan, pemahaman peraturan, kewajiban moral, sanksi pajak, dan aplikasi satria pajak) dalam keadaan konstans ( $\mathrm{x}=$ 0 ), maka perusahaan yang menjadi sampel dalam penelitian ini cenderung memiliki kepatuhan wajib pajak yang baik.

2. Hasil pengujian regresi linier berganda menunjukkan bahwa variabel kesadaran wajib pajak memiliki koefisien regresi sebesar 0,320 dengan nilai signifikansi 0,388. Nilai ini lebih besar dari nilai signifikansi $5 \%(0,05)$. Dengan demikian, maka hipotesis pertama yang menyatakan bahwa kesadaran wajib pajak berpengaruh positif terhadap kepatuhan wajib pajak ditolak.

3. Hasil pengujian regresi linier berganda menunjukkan bahwa variabel kualitas pelayanan memiliki koefisien regresi sebesar -0,076 dengan nilai signifikansi 0,271 . Nilai ini lebih besar dari nilai signifikansi $5 \%(0,05)$. Dengan demikian, maka hipotesis kedua yang menyatakan bahwa kualitas pelayanan berpengaruh positif terhadap kepatuhan wajib pajak ditolak.

4. Hasil pengujian regresi linier berganda menunjukkan bahwa variabel pemahaman peraturan memiliki koefisien regresi sebesar 0,431 dengan nilai signifikansi 0,049 . Nilai ini lebih kecil dari nilai signifikansi 5\% $(0,05)$. Dengan demikian, maka hipotesis ketiga yang menyatakan bahwa pemahaman peraturan berpengaruh positif terhadap kepatuhan wajib pajak diterima, artinya semakin baik pemahaman peraturan, maka semakin baik kepatuhan wajib pajak yang dihasilkan, dengan asumsi variabel lainnya dianggap konstan.

5. Nilai koefisien regresi dari variabel kewajiban moral sebesar 0,485 dengan nilai signifikan sebesar 0,113 . Nilai ini lebih besar dari nilai signifikansi $5 \% \quad(0,05)$. Dengan demikian, maka hipotesis keempat yang menyatakan bahwa kewajiban moral berpengaruh positif terhadap kepatuhan wajib pajak ditolak.

6. Hasil pengujian regresi linier berganda menunjukkan bahwa variabel sanksi pajak memiliki koefisien regresi sebesar $-0,077$ dengan nilai signifikansi 0,752 . Nilai ini lebih besar dari nilai signifikansi 5\% $(0,05)$. Dengan demikian, maka hipotesis kelima yang menyatakan bahwa sanksi pajak berpengaruh positif terhadap kepatuhan wajib pajak ditolak.

7. Hasil pengujian regresi linier berganda menunjukkan bahwa variabel aplikasi satria pajak memiliki koefisien regresi sebesar 0,565 dengan nilai signifikansi 0,003 . Nilai ini lebih kecil dari nilai signifikansi 5\% $(0,05)$. Dengan demikian, maka hipotesis keenam yang menyatakan bahwa aplikasi satria pajak berpengaruh positif terhadap kepatuhan wajib pajak diterima, artinya semakin tinggi penggunaan aplikasi satria pajak, maka semakin baik kepatuhan wajib pajak yang dihasilkan, dengan asumsi variabel lainnya dianggap konstan.

Tabel 5 Hasil Pengujian Koefisien Determinasi

\begin{tabular}{lrrrr}
\hline Model & $\mathrm{R}$ & $\mathrm{R}$ Square & $\begin{array}{l}\text { Adjusted } \\
\text { R Square }\end{array}$ & $\begin{array}{c}\text { Std. Error of the } \\
\text { Estimate }\end{array}$ \\
\hline 1 &, $697^{\mathrm{a}}$ &, 486 &, 380 & 2,14927 \\
\hline
\end{tabular}


Tabel 5 menunjukkan nilai adjusted $R$ square sebesar 0,380 atau $38 \%$, hal ini menunjukkan bahwa variabel kesadaran wajib pajak, kualitas pelayanan, pemahaman peraturan, kewajiban moral, sanksi pajak, aplikasi satria pajak sebesar $38 \%$. Sedangkan sisanya sebesar $62 \%$ dipengaruhi oleh faktorfaktor lain yang tidak diteliti dalam penelitian ini.

\section{Pembahasan}

Menurut Nasution (2006) kesadaran wajib pajak merupakan sikap wajib pajak yang memahami dan mau melaksanakan kewajibannya untuk membayar pajak dan telah melaporkan semua penghasilannya tanpa ada yang disembunyikan sesuai dengan ketentuan yang berlaku. Hasil pengujian hipotesis pada Tabel 4 menunjukkan bahwa kesadaran wajib pajak tidak berpengaruh terhadap kepatuhan wajib pajak. Hal ini tidak sesuai dengan hipotesis awal yang menyatakan bahwa kesadaran wajib pajak berpengaruh positif terhadap kepatuhan wajib pajak (H1 ditolak). Penelitian ini membuktikan bahwa kesadaran wajib pajak hotel di Kabupaten Banyumas belum mencapai tingkat sebagaimana yang diharapkan. Dilihat dari Tabel 2 Data piutang pajak hotel di Badan Pendapatan Daerah Kabupaten Banyumas tahun 2014-2019 masih terdapat piutang pajak sebesar 8.672.720. Artinya ketika Wajib Pajak memiliki kesadaran maka membayar pajak akan dilakukan secara sukarela bukan keterpaksaan. Dengan demikiankesadaran wajib pajak dalam penelitian ini tidak berpengaruh terhadap kepatuhan wajib pajak.

Kualitas pelayanan adalah serangkaian perbuatan nyata yang dilakukan untuk mewujudkan pemberian layanan yang terbaik bagi Wajib Pajak (Kotler, 2002). Hasil pengujian hipotesis pada Tabel 4 menunjukkan bahwa kualitas pelayanan tidak berpengaruh terhadap kesadaran wajib pajak.Hal ini tidak sesuai dengan hipotesis awal yang menyatakan bahwa kualitas pelayanan berpengaruh positif terhadap kesadaran wajib pajak $\left(\mathrm{H}_{2}\right.$ ditolak). Hasil ini menunjukkan bahwa tidak semua perusahaan perhotelan di Kabupaten Banyumas merasakan pelayanan maksimal yang diberikan oleh pegawai Badan Pendapatan Daerah Kabupaten Banyumas.Contohnya dari hasil wawancara dengan manajer hotel Gunung Slamet yang menyatakan bahwa kurang adanya perhatian secara individu terhadap Wajib Pajak hotel.Artinya, Pelayanan disebut prima jika mampu memuaskan Wajib Pajak atau sesuai harapan Wajib Pajak.Instansi yang belum memiliki standar pelayanan perlu menyusun standar pelayanan sesuai tugas dan fungsinya agar tingkat keprimaan pelayanan dapat diukur. Kepuasan masyarakat ini merupakan salah satu ukuran berkualitas atau tidaknya pelayanan publik.Dengan demikian kualitas pelayanan dalam penelitian ini tidak mempengaruhi kepatuhan wajib pajak.

Pemahaman peraturan perpajakan adalah proses dimana Wajib Pajak mengetahui tentang perpajakan dan mengaplikasikan pengetahuan itu untuk membayar pajak (Kiryanto, 2000). Hasil pengujian hipotesis pada Tabel 4 menunjukkan bahwa pemahaman peraturanberpengaruh positif terhadap kepatuhan wajib pajak.Hal ini sesuai dengan hipotesis awal yang menyatakan bahwa pemahaman peraturanberpengaruh positif terhadap kepatuhan wajib pajak $\left(\mathrm{H}_{3}\right.$ diterima).Hal ini sejalan dengan penelitian yang dilakukan oleh Nirajenani dan Aryani (2018), yang membuktikan bahwa pemahaman peraturan berpengaruh positif terhadap kepatuhan wajib pajak. Penelitian ini membuktikan bahwa pemahaman peraturan berpengaruh positif terhadap kepatuhan wajib pajak. Artinya, dalam membayar pajak seorang Wajib Pajak telah memahami bahwa pajak merupakan bentuk partisipasi dalam usaha pembangunan nasional, mengetahui fungsi dari perpajakan, serta Wajib Pajak mengetahui bahwa mereka diberi kepercayaan untuk menghitung, mengisi, membayar dan melaporkan pajaknya sendiri, sehingga dengan adanya pemahaman peraturan dapat meningkatkan kepatuhan wajib pajak, maka semakin baik pemahaman peraturan, maka semakin baik pula kepatuhan wajib pajak. Seperti terlihat pada Tabel 4. Rata-rata aktual sebesar12,1944 dan standar deviasi 1,78597 sedangkan rata-rata teoritisnya 9. Karena rata- 
rata aktual lebih tinggi daripada rata-rata teoritis, sehingga dapat dijelaskan bahwa responden dalam penelitian ini memiliki pengetahuan yang baik tentang pemahaman peraturan.

Bobek dan Hatfield (2003) mengatakan kewajiban moral merupakan suatu perasaan bersalah yang dimiliki seseorang namun belum tentu dimiliki oleh orang yang lainnya.Hasil pengujian hipotesis pada Tabel 4 menunjukkan bahwa kewajiban moral tidak berpengaruh terhadap kepatuhan wajib pajak. Hal ini tidak sesuai dengan hipotesis awal yang menyatakan bahwa kewajiban moral berpengaruh positif terhadap kepatuhan wajib pajak $\left(\mathrm{H}_{4}\right.$ ditolak). Penelitian ini menunjukkan bahwa kewajiban moral tidak berpengaruh terhadap kepatuhan wajib pajak. Menurut kepala sub bidang penagihan terdapat hampir setengah lebih dari jumlah Wajib Pajak hotel yang terlambat bayar pajak. Artinya, sebagian besar Wajib Pajak perhotelan di Kabupaten Banyumas belum sepenuhnya memiliki kemauan yang kuat untuk bertanggungjawab dalam kewajiban perpajakannya dan tidak memiliki perasaan cemas dan perasaan bersalah jika belum memenuhi kewajiban perpajakannya.

Sanksi pajak merupakan alat kontrol yang mengontrol agar wajib pajak tetap memenuhi kewajiban perpajakannya dikarenakan dengan adanya kerugian yang akan didapat oleh wajib pajak apabila tidak membayarkan pajak, yang secara otomatis akan membuat wajib pajak harus berpikir apabila tidak ingin memenuhi kewajiban perpajakannya (Resmi, 2012). Hasil pengujian hipotesis pada Tabel 4 menunjukkan bahwa sanksi pajak tidak berpengaruh terhadap kepatuhan wajib pajak.Hal ini tidak sesuai dengan hipotesis awal yang menyatakan bahwa sanksi pajak berpengaruh positif terhadap kepatuhan wajib pajak $\left(\mathrm{H}_{5}\right.$ ditolak). Penelitian ini menunjukkan bahwa sanksi pajak tidak berpengaruh terhadap kepatuhan wajib pajak.Menurut kepala sub bidang penagihan tanggal jatuh tempo pembayaran pajak hotel yaitu setiap tanggal 10 bulan berikutnya, dan sanksi yang diberikan hanya denda administrasi $2 \%$ per bulan. Maksimal keterlambatan 2 tahun atau 48\%.Dari jumlah sanksi administrasi yang cukup kecil ini, membuat hampir setengah lebih dari Wajib Pajak terlambat membayar pajak.

Aplikasi satria pajak merupakan sistem pembayaran pajak daerah secara online pada Badan Pendapatan Daerah Kabupaten Banyumas. Aplikasi satria pajak melayani pajak hotel, pajak restoran, pajak hiburan, pajak reklame, pajak penerangan jalan, pajak mineral bukan logam dan batuan, pajak parkir, pajak air tanah.Hasil pengujian hipotesis pada Tabel 4 menunjukkan bahwa aplikasi satria pajakberpengaruh positif terhadap kepatuhan wajib pajak. Hal ini sesuai dengan hipotesis awal yang menyatakan bahwa aplikasi satria pajakberpengaruh positif terhadap kepatuhan wajib pajak $\left(\mathrm{H}_{6}\right.$ diterima). Hal ini sejalan dengan hasil wawancara dengan Pak Toro kepala sub bidang penagihan Badan Pendapatan Daerah Kabupaten Banyumas aplikasi satria pajak merupakan sistem pembayaran pajak daerah secara online yang sangat berpengaruh terhadap tingkat kepatuhan wajib pajak hotel di kabupaten Banyumas. Penelitian ini membuktikan bahwa aplikasi satria pajakberpengaruh positif terhadap kepatuhan wajib pajak. Artinya dalam membayar pajak, seorang Wajib Pajak dapat dengan mudah melakukan kewajiban perpajakannya hanya dengan mengakses aplikasi satria pajak melalui website resmi

https://satriapajak.banyumaskab.go.id.

Menurut kepala sub bidang penagihan selain mempermudah Wajib Pajak dalam membayar kewajiban perpajakannya, aplikasi satria pajak juga mempermudah pegawai Badan Pendapatan Daerah khususnya bidang penagihan dalam memonitor pajak daerah.

\section{KESIMPULAN}

Penelitian ini menyimpulkan bahwa wajib Pajak menganggap bahwa kesadaran membayar pajak dalam suatu kegiatan perpajakan kurang memberikan manfaat. Selain itu kualitas pelayanan yang diberikan tidak dapat meningkatkan kepatuhan wajib pajak. Kewajiban moral juga yang diberikan tidak dapat meningkatkan kepatuhan wajib 
pajak. Sanksi pajak yang diberikan tidak dapat meningkatkan kepatuhan wajib pajak. Namun semakin baik pemahaman peraturan dalam melaksanakan kewajiban perpajakannya, maka semakin baik pula kepatuhan wajib pajak dan semakin baik aplikasi satria pajakdalam melaksanakan kewajiban perpajakannya, maka semakin baik pula kepatuhan wajib pajak.

Beberapa saran yang penulis berikan sehubungan dengan penelitian yang dilakukan adalah adalah bagi Badan Pendapatan Daerah Kabupaten Banyumas, diharapkan lebih memperhatikan faktor-faktor yang dapat meningkatkan kepatuhan wajib pajak hotel, sehingga pemerintah berhasil dalam menghimpun pajak. Bagi Wajib Pajak hotel, hendaknya bisa menjadikan penelitian ini sebagai bahan pertimbangan agar dapat lebih memahami pentingnya kepatuhan dalam membayar pajak, sehingga dapat meningkatkan kepatuhan pajak. Dalam penelitian ini tidak terlepas dari beberapa keterbatasan, diantaranya adalah sampel yang digunakan dalam penelitian ini sangat kecil dan hanya terbatas pada wajib pajak hotel di Kabupaten Banyumas, sehingga penelitian ini tidak dapat digeneralisasi untuk jenis perusahaan lainnya. Hal ini yang dapat memungkinkan adanya perbedaan hasil dan kesimpulan. Sehingga agenda penelitianyang akan dating dapat menambah jumlah sampel sehingga gambaran hasil penelitian lebih mendekati kondisi yang sebenarnya.

\section{Daftar Pustaka}

Ajsen. 2002. Constructing a TBP Questionnaire : Conceptual and Mmethodological Considerations. September (Revised January, 2006)

Alabede et al. 2011. Tax Service Quality and Compliance Behaviour in Nigeria: Do Taxpayer's Financial Condition and Risk Preference Play Any Moderating Role?.European Journal of Economics, Finance and Administrative Sciences, 35: p: 90-108.
Anatan \& Ellitan.2007. Manajemen Sumber Daya Manusia Dalam bisnis Modern. Alfabeta. Bandung.

Arikunto Suharmi. (2012). Prosedur Penelitian Suatu Pendekatan Praktek. Rineka Cipta. Jakarta.

Asri. 2009. Pengaruh Kualitas Pelayanan, Biaya Kepatuhan Pajak, dan Kesadaran Wajib Pajak pada Kepatuhan Pelaporan Wajib Pajak Badan yang Terdaftar di Kantor Pelayanan Pajak Madya Denpasar. Skripsi Jurusan Akuntansi Pada Fakultas Ekonomi Universitas Udayana.

Bobek dan Hatfield. 2003. An Investigation of The Theory of Planned Behavior and The Role of Moral Obligation in Tax Compliance. Behavioral Research in Accounting, Vol 15.

Budhiarta. 2013. Pengaruh kesadaran wajib pajak, pengetahuan pajak, sanksi perpajakan, dan akuntabilitas pelayanan publik pada kepatuhan wajib pajak kendaraan bermotor. E- Jurnal Akuntansi Universitas Udayana, 4(2), 345-357.

Burhanudin. 2009. Service Quality Dimensions in Public Sector. Jurnal Ekonomi Bisnis \& Akuntansi Ventura, 12 (2) h:129-136.

Chau. 2009. A Critical Review of Fischer Tax Compliance Model. Journal of Accounting and Taxation.

Chen dan tan. 2004. Effect of Organizational Learning Culture on Service Quality and Performance of Thai Accounting Firms. International Journal of Business Research.

Dewi danSukartha.2015.Faktor-Faktor Yang Mempengaruhi Kepatuhan Wajib Pajak Dalam Membayar Pajak Hotel.E-Jurnal Akuntansi Universitas Udayana, 13(2), 599-614. 
Dewi dan Aryani.2018. Pengaruh Kesadaran Wajib Pajak, Sanksi Perpajakan, EFiling, dan Tax Amnesty Terhadap Kepatuhan Pelaporan Wajib Pajak. https://doi.org/10.24843/EJA.2018.v2 2.102.p30

Dharma dan Suardana. 2014. Pengaruh kesadaran wajib pajak, sosialisasi perpajakan, kualitas pelayanan pada kepatuhan wajib pajak. E-Jurnal Akuntansi Universitas Udayana 6.1 (2014) 340-353.

Eriksen. 1996. Tax Knowledge and Attitudes Toward Taxation on a Quasi Experiment. Journal of Economic Psychologi, Vol 8, No. 3.

Ghozali dan Chariri. 2007. Teori Akuntansi. Semarang: Badan Penerbit Universitas Diponegoro.

Green. 1991. Health Promotion Planning; An Educational and Environtmental Approach. London: Mayfield Publishing Company.

Harahap. 2004. Analisis kritis atas laporan keuangan. Jakarta: PT Raja Grafindo Persada.

Haryanti, S., \& Kaukab, M. E. (2019). Analisis Transparansi Dan Akuntabilitas Laporan Keuangan Masjid Di Wonosobo (Sstudi Empiris Pasa Masjid Yang Terdaftar Di Kemenag Kabupaten Wonosobo Tahun 2019). Journal of Economic, Business and Engineering (JEBE), 1(1), 140-149.

https://www.pajak.go.id/id/artikel/membangu n-kesadaran-dan-kepedulian-sukarelawajib-pajak

https://lenteratoday.com/pentingnyapenjaminan-kualitas-pelayanan-publik/

https://www.klikpajak.id https://www.online-pajak.com

https://smartcity.bandung.go.id/forum/thread/r $\underline{\mathrm{ead} / 1 / 1 / 286}$

https://ekstensifikasi423.blogspot.com/2014/1 0/mengenal-sanksi-pajak.html?m=1

Hutagaol.2007. Perpajakan Isu-isu Kontemporer .Jakarta: Graha Ilmu.

Imam Ghozali. (2006). Aplikasi Analisis Multivariate Dengan Program SPSS23. Badan Penerbit Universitas Diponogoro. Semarang. Edisi 4

Imam Ghozali. 2011. Aplikasi Analisis Multivariate Dengan Program IBM SPSS 19. Edisi Kelima. Badan Penerbit UNDIP Semarang.

Imam Ghozali. (2013). Aplikasi Analisis Multivariate Dengan Program SPSS23. Badan Penerbit Universitas Diponogoro. Semarang. Edisi 7

Indriyani dan Sukartha. 2014. Tanggung Jawab Moral, Kesadaran Wajib Pajak, Sanksi Perpajakan Dan Kualitas Pelayanan Pada Kepatuhan Pelaporan Wajib Pajak Badan. E-Jurnal Akuntansi Universitas Udayana.

James dan Alley. 2002. Tax Complience, SelfAssessment and Tax Adminitration. Journal Of Finance And Management In Public Service. Vol 2 No 2.

James et al. 2004. Tax Complience, Self Assessment and Tax Adminitration.Journal Of Finance And Management In Public Service.

Jatmiko. 2006. Pengaruh Sikap Wajib Pajak Pada Pelaksanaan Sanksi Denda, Pelayanan Fiskus dan Kesadaran Perpajakan Terhadap Kepatuhan Wajib Pajak.

Jaya dan Jati. 2016. Pengaruh kesadaran, kualitas pelayanan, pemeriksaan dan 
sanksi perpajakan pada kepatuhan wajib pajak restoran.E- Jurnal Akuntansi Universitas Udayana, 16(1), 471-500.

KBBI. 2005. Pemahaman Peraturan.

Kerlinger. 2006. Asas - asas Penelitian Behaviour. Edisi 3, Cetakan 7. Yogyakarta : Gadjah University Press.

Kiryanto. 2000. Analisis Pengaruh Penerapan Struktur Pengendalian Intern terhadap Kepatuhan Wajib Pajak Dalam Memenuhi Kewajiban Pajak Penghasilannya. EKOBIS, Vol.1 No.1, hlm.41-52.

Kotler. 2002. Manajemen Pemasaran, Edisi Milenium. Jakarta: PT. Prehalindo.

Lederman. 2003. The Interplay Between Norms and Enforcement in Tax Compliance. Ohio State Law Journal.64(6): h:1453-1514.

Layata dan Setiawan.2014. Pengaruh kewajiban moral, kualitas pelayanan, pemeriksaan pajak dan sanksi perpajakan pada kepatuhan wajib pajak badan. E- Jurnal Akuntansi Universitas Udayana, 9(2), 540-556.

Mardiasmo. 2011. Perpajakan. Yogyakarta: Andi.

Martin. 2010. Taxprayer Attitudes and Tax Compliance Behavior in Kenya. African Journal of Bussines and Management, 1:h:112-122.

Masyhuri dan Zainuddin. 2008. Metodologi Penelitian Sosial dan Ekonomi, Teori dan Aplikasi. Penerbit Alfabeta, Bandung.

Munawaroh. 2018. Pengaruh Kualitas Pelayanan, Pemahaman Peraturan Perpajakan dan Kesadaran Wajib Pajak Terhadap Kepatuhan Wajib Pajak. Journal.umpo.ac.id
Nasution, Chairuddin Syah. 2003. "Analisis Potensi Dan Pertumbuhan Penerimaan Pajak Penghasilan (PPh) Di Indonesia Periode 1990 - 2000". Kajian Ekonomi Dan Keuangan, Vol. 7, No. 2.

Ngakil, I., \& Kaukab, M. E. (2020). Transparansi dan Akuntabilitas Pengelolaan Keuangan Desa di Kabupaten Wonosobo. Journal of Economic, Management, Accounting and Technology (JEMATech), 3(2), 92107.

Nirajenani dan Aryani. 2018. Faktor-faktor yang Mempengaruhi Kepatuhan Wajib Pajak dalam Membayar Pajak Kendaraan Bermotor. E- Jurnal Akuntansi Universitas Udayana, 24(1), 339-369.

Noormala. 2008. Voluntary Compliance : Tax Education. International Conference on Bussiness and Economy 6-8 November 2008 Constanta Romania. International Islamic University Malaysia : 30-40.

Parasuraman. 1988. Servqual: A MultipleItem Scale for Measuring Consumer Perceptions of Service Quality. Journal of Retailling, Volume 64, Pp 12-40.

Pranata dan Setiawan. 2015. Pengaruh Sanksi Perpajakan, Kualitas Pelayanan dan Kewajiban Moral pada Kepatuhan Wajib Pajak.E-Jurnal Akuntansi Universitas Udayana, 10(2), 456-473. https://doi.org/10.1152/japplphysiol.011 $\underline{64.2001}$

Pratiwi dan Supadmi. 2016. Pengaruh Pemahaman Peraturan, Administrasi, dan Sanksi Perpajakan Pada Kepatuhan Wajib Pajak Hotel.

Pratiwi dan Aryani. 2019. Pengaruh kualitas pelayanan, kewajiban moral, sanksi pajak dan tapping box pada kepatuhan 
wajib pajak hotel. E- Jurnal Akuntansi Universitas Udayana, 26 (1), 231-260.

Priambodo. 2017. Pengaruh Pemahaman Peraturan Pajak, Sanksi Perpajakan, dan Kesadaran Wajib Pajak, terhadap Kepatuhan Wajib Pajak Orang Pribadi di Kantor Pelayanan Pajak Pratama Kabupaten Purworejo pada Tahun 2017. Skripsi Fakultas Ekonomi Universitas Negeri Yogyakarta.

Pusparini. 2016. Pengaruh Pemahaman Wajib Pajak dan Pelaksanaan Sanksi Pajak Terhadap Kesadaran Wajib Pajak Orang Pribadi. Skripsi UI: Jakarta.

Radarbanyumas, 2019.

Rahayu.2010. Perpajakan Indonesia Konsep Dan Aspek Formal. Yogyakarta: Graha Ilmu.

Rahayu.2015. Pengaruh Kualitas Pelayanan, Kewajiban Moral Dan Sanksi Perpajakan Terhadap Kepatuhan Wajib Pajak Hotel Dalam Membayar Pajak Hotel.Jom FEKON Vol.2 No.2 Oktober 2015.

Resmi. 2008. Perpajakan Teori dan Kasus. Edisi Ketiga. Jakarta: Salemba Empat.

Resmi. 2012. Perpajakan: Teori dan Kasus. Jakarta: Salemba Empat.

Sucahyani dan Sukartha. 2017. Pengaruh pengetahuan, pelayanan, biaya kepatuhan, dan sanksi pada kepatuhan wajib pajak dalam membayar pajak hotel.E- Jurnal Akuntansi Universitas Udayana, 26 (2), 1357-1358.

Sucandra dan Supadmi. 2016. Pengaruh kualitas pelayanan, pemeriksaan pajak, pengetahuan perpajakan dan sanksi perpajakan pada kepatuhan wajib pajak restoran. E- Jurnal Akuntansi Universitas Udayana, 16(2), 12101237. Retrieved from
https://ojs.unud.ac.id/index.php/Akunta nsi/article/view/17610

Sugiono. 2001. Metode Penelitian, Bandung: Alfabeta.

Sugiyono. 2012. Metode Penelitian Kuantitatif Dan Kualitatif Dan R\&D. Bandung: Alfabeta

Sugiono. (2016). Metode Penelitian Administrasi. Alfabeta. Bandung.

Suliyanto. 2011. Ekonometrika Terapan : Teori dan Aplikasi Dengan SPSS. Edisi 1. Yogyakarta: ANDI Yogyakarta.

Susilawati dan Budiartha. 2013. Pengaruh Kesadaran Wajib Pajak, Pengetahuan Pajak, Sanksi Perpajakan dan Akuntabilitas Pelayanan Publik Pada Kepatuhan Wajib Pajak Kendaraan Bermotor. Vol 4, No. 2.

Tjiptono. 2004. Kepuasan dalam Pelayanan. Penerbit Salemba Empat, Jakarta.

Troutman. 1993. Moral Commitment To Tax Compliance as Measured by The Development of Moral Reasoning and Attitutes Towars The Fairness of The Tax Laws. Dissertation, Oklahoma State University. USA.

Undang-Undang nomor 22 Tahun 2016 tentang pajak daerah dan retribusi daerah yang mengatur tentang pajak daerah dan retribusi daerah.

Undang-Undang No. 22 Tahun 2016tentang Peraturan Daerah Kabupaten Banyumas.

Wahyu. 2008. Analisis Risiko Ketidakpatuhan Wajib Pajak Sebagai Dasar Peningkatan Kepatuhan Wajib Pajak (Penelitian terhadap Wajib Pajak Badan di Indonesia). Jurnal Keuangan Publik, 5 (1) h:85-138. 
Webley et.al.1991. Tax Evasion: An Experimental Approach. Cambrdige, United Kingdom: Cambridge University Press.

Wenzel. 2005. Motivation or Rationalization Casual Relation Between Etichs, Norms and Tax Compliance. Journal Of Economics Psychology. 26(24) 491208.

Wibowo dan Yeni. 2013. Analisis Faktorfaktor yang Memotivasi Manajemen Perusahaan Melakukan Tax Planning. Tax and Accounting Review Vol. 1 ( 1)

Yadnyana. 2009. Pengaruh Moral dan Sikap Wajib Pajak pada Kepatuhan Wajib Pajak Koperasi di Kota Denpasar. Fakultas Ekonomi Universitas Udayana, Denpasar. 